\title{
Implementasi e-FAKTUR 2.2 dan PMK 62/PMK03/2015 atas Pupuk Bersubsidi Perspektif Distributor
}

\author{
Endang Sri Midiawati ${ }^{1}$ \\ Fakultas Ekonomi dan Bisnis \\ Universitas Mataram, Indonesia
}

\author{
Titiek Herwanti ${ }^{2}$ \\ Fakultas Ekonomi dan Bisnis \\ Universitas Mataram, Indonesia
}

\author{
Lalu Hamdani Husnan ${ }^{3}$ \\ Fakultas Ekonomi dan Bisnis \\ Universitas Mataram, Indonesia
}

\begin{abstract}
ABSTRAK
E-faktur 2.2 merupakan manifestasi peraturan UU No 42 tahun 2009 tentang Pajak Pertambahan Nilai (PPN) yang tidak mengakomodir subsidi PPN komoditi Pupuk, yang tampak memberi dampak pada SAS PPN bagi Distributor. Penelitian ini bertujuan melihat bagaimana mekanisme implementasi e-faktur pada komoditi pupuk bersubsidi dengan metode ditanggung pemerintah (PPN DTP). Permasalahan umum tentang dasar hukum yang secara tekhnis hanya menerangkan hingga di tingkat produsen. Hasil pengamatan dilakukan secara studi kasus dengan mengolah data tahun 2016 dan seterusnya, menunjukkan terdapat masalah dalam implemntasinya baik dari pengadministrasian dan validasi sistem, serta potensi masalah pada informasi pengawasan dan silang informasi. Terutama pada pengelolaan SAS PPN melalui e-faktur 2.2 pada perspektif distributor.
\end{abstract}

Surel : kalemlady@gmail.com

Kata Kunci: $\quad$ E-Faktur; PPN Subsidi; Pupuk Bersubsidi.

\section{Implementation of e-FACTUR 2.2 and PMK 62/PMK03 / 2015 on Subsidized Fertilizer from Distributor Perspective}

\begin{abstract}
E-fakur 2.2 is a manifestation of Undang-undang No. 42 of 2009 concerning Value Added Tax (VAT) which does not accommodate VAT subsidies for commodity Fertilizer packages which have an impact on SAS VAT for distributors. This study aims to see how the implementation of subsidized fertilizer commodity e-invoices with the government-borne method (PPN DTP). General problems regarding the legal basis which technically only explain down to the producer level. The results of observations in a case study by processing data from 2016 onwards show problems in their implementation, both from administration, validation sistems and developing information on supervision and cross-information, especially on the management of SAS PPN through e-faktur2.2 from the distrbutor perspective.
\end{abstract}

Keywords: E-Faktur; VAT Subsidized; Subsidized Fertilzer.

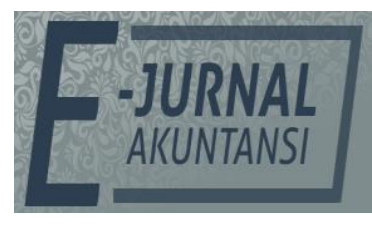

e-ISSN 2302-8556

Vol. 31 No. 1

Denpasar, Januari 2021

Hal. 63-76

DOI:

10.24843/EJA.2021.v31.i01.p05

PENGUTIPAN:

Midiawati, S. M., Herawati,

T. \& Husnan, L.H. (2021).

Implementasi e-FAKTUR 2.2 dan PMK 62/PMK03/2015

atas Pupuk Bersubsidi

Perspektif Distributor EJurnal Akuntansi, 31(1), 63-76

RIWAYAT ARTIKEL: Artikel Masuk: 29 September 2020 Artikel Diterima: 11 Januari 2021

Artikel dapat diakses : https://ojs.unud.ac.id/index.php/Akuntansi/index 


\section{PENDAHULUAN}

Undang-Undang Ketentuan Umum Perpajakan tahun 2007 pasal 1 [satu] yang menyatakan bahwa, "pajak merupakan kontribusi wajib kepada Negara, oleh orang pribadi atau badan yang bersifat memaksa. Berdasarkan Undang- Undang dengan tidak mendapatkan imbalan secara langsung dan digunakan untuk keperluan negara bagi sebesar-besarnya kemakmuran rakyat. Inilah fungsi budgetair pajak sebagai sumber penerimaan Negara, namun menjadi biaya bagi hampir semua jenis usaha (Das, n.d.) dan pengurang pendapatan warga Negara. Proses pemenuhannya merupakan salah satu proses transfer daya beli sekaligus input informasi dari sektor non pemerintah, dilakukan secara Self Asessment Sistem (SAS) yang terakomodir dalam pembaharuan sistem e-SPT, e-faktur dan $e$ filling.

Self asessment sistem merupakan suatu pola yang diterapkan oleh Direktorat Jenderal Pajak setelah adanya reformasi pajak tahun 1993, beberapa penelitian terkait hal ini memaparkan bahwa tingkat pemahaman wajib pajak tentang self asessment dalam pola menghitung, menentukan dan melaporkan adalah baik (Andryani, 2012). Sedangkan tingkat pemahaman (Wibowo et al., 2017) dan (Sudrajat et al., 2015) menghasilkan simpulan bahwa pengetahuan yang baik akan berpengaruh positif terhadap kepatuhan perpajakan dan pengetahuan tidak menjadi satu satunya factor positif, melainkan pemanfaatan tekhnologi dan sosialisasi juga memiliki pengaruh signifikan terhadap kepatuhan (Sudrajat et al., 2015) dan (Komal \& Sirifort, 2013). Dalam operasionalnya, penguasaan self assessment yang baik juga akan dapat memberikan peluang kepada wajib pajak untuk melakukan perencanaan terhadap pajaknya (Sarjana et al., n.d.).

Pajak Pertambahan Nilai (PPN), merupakan jenis pajak dengan pemutakhiran aplikasi pelaksanaan Self Asessment System (SAS) yang lebih aktif dibanding pajak lainnya. Hal ini tidak hanya di Indonesia, tercatat sejak 2015 Portugal, Brazil Malaysia dan cina melakukan pemutakhiran sistem dengan menitik beratkan pada database, sistem silang informasi dan approval system pada penginputan pembelian dan penjualan barang/jasa (je bello dalam (Timmermans \& Achten, 2018)

Pajak Pertambahan Nilai bukanlah pajak yang populer untuk dikembangkan namun merupakan alat yang paling dominan dalam menambah pendapatan sektor pajak (Copenhagen Economics, 2013) dan . Sebagaimana di Indonesia PPN masih memegang kontribusi terbesar dari total penerimaan pajak dalam negeri. Namun beban tarif yang cukup besar sebab membebani rantai proses penyerahan atau papun yang mengkibatkan petambahan nilai dari barang / jasa yaitu 10\% dari selisih antara penjualan dan pembelian. Namun terdapat ketentuan khusus yang mengikat pada jenis barang tertentu sebagaimana diatur dalam aturan tersendiri antara lain fasilitas PPN dibebaskan, PPN tidak terutang, PPN tidak dipungut bahkan PPN ditanggung pemerintah. Fasilitas tersebut menjadikan rantai PPN menjadi tidak berbeban pada rantai pertambahn nilai barang di setiap jenjangnya.

Apapun mekanisme dan fasilitas pada SAS PPN, semua diatur dalam UU No 42 tahun 2009 tentang Pajak Pertambahan Nilai yang termanifestasi dalam aplikasi e-faktur 2.2. Konsep Pajak ditanggung pemerintah termuat dalam 
PMK No 228/200 jo PMK 237/2011 “Pajak DTP adalah pajak terutang yang dibayarkan oleh pemerintah dengan pagu anggaran yang telah ditetapkan dalam Anggaran Pendapatan dan Belanja Negara( APBN), kecuali ditentukan lain dalam Undang Undang dan APBN". Salah satu jenis DTP yang dimaksud dalam definisi di atas adalah Pajak Pertambahan Nilai yang menjadi beban pemerintah pada setiap peredaran barang/jasa dimaksud ( produsen hingga konsumen).

Sebagaimana temuan BPK melalui bahwa subsidi PPN ditanggung pemerintah "tidak terakomodir dalam UU No 42 tahun 2009 "(NURMA ARI WIDYANINGRUM, 2012) sedangkan regulasi ini adalah manifestasi efaktur 2.2. Komoditi Pupuk bersubsidi merupakan salah satu barang yang disubsidi, Pemberlakuannya antara lain diatur dalam PMK 62/PMK.03/2015. Jenisnya antara lain pupuk pertanian Urea, NPK, SP36, ZA dan Organik(Sudjono, 2016). Jika terdapat ketidakpatutan dalam pelaksanaan operansional SAS PPNnya, tentu dapat menjadi sumber masalah bagi pelaksananya(Dečman \& Klun, 2015). Mengingat e-faktur 2.2 adalah aplikasi administrasi pemajakan PPN dalam mengoperasionalkan data transaksi, membuat bukti, menghitung pajak sekaligus membuat SPTnya.

Sejauh pantaun peneliti, penelitian sebelumnya masih jarang yang mengkaji permasalahan regulasi serta implementasi e-faktur 2.2 sebagai alat administrasi pemajakan pupuk berubsidi, yaitu mengenai seberapa jauh data transaksi layak untuk diolah dalam menghasilkan informasi yang relevan dengan kepatuhan pajak. Sehingga dapat dipastikan hal pokok dalam mekanisme rantai jalurnya adalah dengan melihat kelayakan bukti transaksi, kesiapan user dan akomodasi dalam aplikasi yang tersedia. Agar fungsi e-faktur dalam memudahkan melakukan standarisasi faktur pajak, validasi bukti pajak masukan dan keluaran serta memudahkan pelaporan dapat memberikan dampak positif dalam pengawasan kepatuhan wajib pajak (Tripathi et al., 2011), (Dečman \& Klun, 2015) dan tidak berlaku sebaliknya (Muir, 1993).

Adapun PPN berlaku rantai pemungutan dan Peraturannya bagi Pengusaha Kena Pajak(PKP) Merupakan Pengusaha dengan kualifikasi tertenu antara lain : (1) mengajukan diri sebagai pengusaha kena pajak dan atau(2) memiliki omset lebih dari 4.800.000.000 ( Empat Milyar Delapan Ratus Juta Rupiah), baik dalam satu waktu ataupun akumulasi selama 1 tahun transaksi baik tahun buku ataupun tahun takwim (3) memenuhi kriteria lainnya yaitu persetujuan setelah survey.

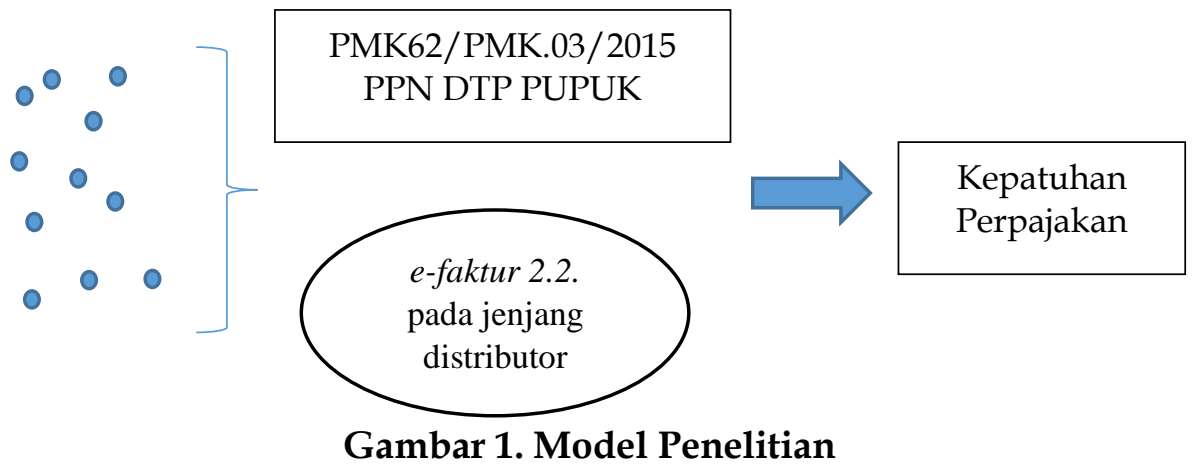

Sumber: Data Penelitian, 2020 
Dalam hal permasalahan perpajakan PPN DTP, pembahasan harus dilansir dari perusahaan distributor dengan status PKP. Keseragaman peraturan terkait aturan penebusan, penyaluran, dan status produsen tunggal membuat rantai penyaluran dapat diamati dengan studikasus mendalam pada distributor PNTB guna melihat pemasalahan awal, peluang dan solusi yang mungkin di berikan dalam permasalahan PPN DTP.

Sebagai manifestasi dari undang -undang dan juknis turunan umum seperti, e-faktur 2.2 dihadapkan pada UU 42 Tahun 2009 tentang Pajak Pertambahan Nilai, PMK 151/PMK 03/2013, Per 24/PJ/2012, PER 16/PJ/2014 dan PER 1/PJ/2014. Sepatutnya penguasaan user terhadap aplikasi akan sudah secara atomatis mengakomodir terpenuhinnya aturan di atas. Akan tetapi kendala sistem elektronik seperti penggunaan internet, loading sistem, dan kedala penomeran via enofa merupakan masalah rutin yang ditemui pada pengaplikasiannya (Gisbu et al., 2015). Mengatasi kendala diatas dibutuhkan kecermatan dari user tentang ketelitian waktu dan penguasaan aplikasi seolah menjadi lebih utama dari aturan itu sendiri. Ditambah pemberlakuan PPN DTP PMK 62/PMK.03/2015 yang tidak tercakup dalam UU No 42 tahun 2009.

Pembaharuan sistem secara terus menerus sejak juli 2016(Musri, 2019) mulai dari versi 1.1 hingga aplikasi e-faktur 2.2 menuju penerbitan bukti transaksi yang layak, pengamanan bukti pembelian yang sah (tidak fiktif). Mengingat bahwa pajak "dapat dipaksakan", " berdasarkan undang-undang" dan "bernilai beban pada setiap ketidaksesuaian pada aturan" yang dilakukan, maka bagaimanakah permasalahan distributor Pupuk bersubsidi yang mendapatkan subsidi PPN DTP dalam aplikasi e faktur?

\section{METODE PENELITIAN}

Penelitian ini menggunakan metode kualitatif deskfriptif dengan grounded theory, artinya menurut sugiyono(2017) adalah metode penelitian yang didasarkan pada postpositivisme atau enterpretif, digunakan untuk meneliti pada kondisi obyek yang alamiah, dimana peneliti sebagai instrument kunci. Tekhik pengumpulan data dilakukan secara triangulasi (gabungan observasi, wawancara dan dokumentasi), data yang diperoleh cenderung data kualitatif, analisis data bersifat thematic analisis dari data yang bersifat kualiatif. Bertujuan untuk memahami keunikan, mengkonstruksi fenomena dan menemukan hipotesis. Metode grounded sendiri merupakan salah satu macam metode kualitatif yang bersifat berfokus pada partisipan yang diamati yaitu manajerial, user aplikasi / mitra administrasi perpajakan Badan Usaha PNTB, dan account representative KPP Pratama Lokasi pada masa penelitian dilakukan.

Teori yang digunakann sebagai referensi dalam membantu penelitian ini adalah teori kepatuhan yang didasarkan pada 544/KMK.04/2000 wajib pajak patuh adalah sebagai berikut (1) Tepat waktu menyampaikan SPT untuk semua jenis pajak dalam 2 tahun terakhir, (2) Tidak mempunyai tunggakan pajak untuk semua jenis pajak kecuali telah memperoleh ijin untuk mengangsur atau menunda pembayaran pajak, (3) Tidak pernah dijatuhi hukuman karena melakukan tindak pidana dibidang perpajakan dalam jangka waktu 10 tahun terakhir dan (4) Dalam 2 tahun terakhir menyelenggarakan pembukuan dan 
dalam hal terhadap wajib pajak yang sudah dilakukan pemeriksaan yang terakhir untuk tiap tiap jenis pajak yang terutang paling banyak $5 \%$.

Badan Usaha PNTB merupakan badan usaha yang berwenang mengatur pendistribusian pupuk di Lombok Utara, Lombok Barat, Lombok Timur dan Kota Mataram. PNTB di KPP terdaftar adalah aktif sebagai Pengusaha Kena Pajak, sehingga wajib menerbitkan dan merekam bukti standarisasi pajak atas seluruh transaksi barang dan jasa lalu melaporkannya pada SPT masa PPN. Penelitian ini megunakan data primer dan sekunder dari PNTB berupa faktur lawan transaksi / pembelian, faktur keluaran (penjualan), data pengiriman dari lawan transaksi, surat menyurat, SPT bulanan PPN yang dilaporkan PNTB dan hasil wawancara informan. Informan kuncinya adalah Direktur Operasional, sebab mengijinkan proses penelitian dan menguasai seluruh jalur informasi baik lapangan dan administrasi. Secara snowball, informan kunci mengarahkan pada informan tambahan yaitu bagian adminstrasipembukuan dan perpajakan untuk memperjelas proses yang diamati dan selanjutnya kepada Account Reresentatif. Hasil wawancara akan saling mengoreksi dengan data sekunder dan regulasi PPN pada aplikasi e-faktur 2.2.

\section{HASIL DAN PEMBAHASAN}

SAS PPN e-faktur 2.2 menganut sistem indirect credit atau atau pengkreditan pajak masukan. Adapun sistem ini secara komersial data digambarkan sebagai berikut (Inside taxed Ed 33:2015:8).

Sistem Indirect Credit $=$ ' $\mathrm{t}$ (output) ${ }^{\prime} \mathrm{t}$ (input)

Keterangan :

't $\quad=$ pajak

'output $=$ seluruh tranksi penjualan

'input =seluruh transaksi pembelian

Besarnya Pajak Pertambahan Nilai Terutang adalah hasil pengurangan seluruh PPN penjualan dan PPN pembelian. Penerapan menghitung, menentukan dan melaporkan PPN menggunkan e-faktur2.2 yaitu dengan mekanisme penginputan penjualan, pembelian dan approval sistem dengan prinsip kerja database dan sitem silang informasi . Prinsip kerja sistem ini juga berlaku dibeberapa negara didunia dalam pemutakhiran sistem pajaknya, sistem silang informasi ini secara internal adalah proses yang memungkinkan pengecekan kabsahan bukti (Han, et al., 2019) yang diterima dari rekanan dari penjual oleh pembeli dan bagi penjual salah satunya mengenai terpenuhi syarat, bentuk, ukuran dan keabsahan nomor seri dokumen transaksi yang diterbitkan.

Faktur Pajak Masukan adalah faktur pajak yang diterima sebagai akibat hubungan rantai pembelian dan pengadimnistrasian perpajakan e-faktur2.2 dilakukan pada laman Administrasi pajak masukan. Sedangkan Faktur pajak keluaran adalah faktur yang diterbitkan oleh penjual dalam hal ini sebagai bukti penjualan dan pengadimnistrasian perpajakannya e-faktur2.2 dilakukan pada laman Administrasi pajak keluarandan akan melalui proses approval . Adapun status pada bagian administrasi Faktur (baik masukan maupun keluaran) terdapat kolom status approval antara lain. (pajak.go.id) (1) Belum Approve (untuk Faktur Pajak yang belum di-upload/dilaporkan ke Direktorat Jenderal Pajak, DJP, (2) Siap Approve (untuk Faktur Pajak yang sudah diupload (tidak 
dapat diubah), menunggu dilakukannya start uploader pada menu management upload-upload faktur), (3) Approval Sukses (menunjukkan Faktur Pajak yang telah dilaporkan dan memperoleh persetujuan DJP), (4) Reject (menunjukkan Faktur Pajak yang ditolak sistem disebabkan hal tertentu misal Nomor seri Faktur Pajak bukan jatah Pengusaha Kena Pajak, PKP), dan (5) Bukan Faktur eTax (merupakan status Approval khusus untuk Pajak Masukan yang diperoleh dari PKP yang belum menggunakan e-Faktur)

\begin{tabular}{|l|l|l|l|l|l|l|l|l|l|l|l|l|l|l|l|}
\hline 0 & 0 & 0 & 9 & 0 & 0 & 1 & 3 & 0 & 0 & 0 & 0 & 0 & 0 & $\mathrm{x}$ & $\mathrm{X}$ \\
\hline
\end{tabular}

\section{Gambar 2. Sistem Penomoran Enofa}

Sumber : Data Penelitian, 2020

E-Faktur 2.2 merupakan pembaharuan sistem informasi tekhnologi pada Pajak Pertambahan Nilai, aplikasi dapat menghindari penyalahgunaan faktur pajak sampai dengan faktur pajak ganda. Peningkatan tekhnologi ini mempermudah adanya pengawasan terkait nomor seri dengan approval sistem dan enofa. Manifestasi regulasi SAS PPN pada PER - 24 /PJ/ 2012 tentang bentuk, ukuran dan tatacara pengisian keterangan, prosedur penggantian dan pembatalan pada menu administrasi user di submenu referensi enofa yang telah terintegrasi dengan peraturan penomeran enofa sesuai dengan PER 24/PJ/2012. Enofa yaitu penomeran 13 digit terakhir dari 16 standar penomeran. Fungsi tiga digit di depan pada menu adiministrasi faktur pajak keluaran menandakan lawan transaksi dan atau fasilitasnya yaitu 02,03,04,06,07,08,09. sesuai PER. Berikut daftar kode pada e-fakur 2.2.

Tabel 1. Daftar kode pada e-fakur 2.2.

\begin{tabular}{ll}
\hline No. Kode & Keterangan \\
\hline 040 & Penyerahan DPP Nilai Lain/ DTP \\
030 & Penyerahan dengan pemungut PPN selain bendaharawan \\
020 & Penyerahan dengan bendaharawan \\
070 & Barang yang PPNnya tidak dipungut \\
060 & Penyerahan kepada pemegang paspor Luar Negeri \\
080 & Barang yang PPNnya dibebaskan \\
090 & Penyerahan Aktiva pasal 16D (sebelumnya tidak untuk dijual) \\
010 & Penyerahan dengan PKP umumnya \\
\hline
\end{tabular}

Sumber: Data Penelitian , 2020

Proses SAS PPN secara umum adalah melakukan penentuan. penghitungan dan pelaporan atas SPT masa PPN selambatnya akhir bulan berikutnya. Sasaran SAS PPN adalah memenuhi kepatuhan perpajakan, menghindari sanksi baik berupa denda ataupun bunga akibat kesalahan pengadminstrasian ataupun keterlambatan. Selanjutnya seluruh informasi yang disampaikan DJP dalam menu e-filling akan mendapatkan pengawasan oleh sytem DJP. Pengawasan dapat dilakukanantara lain dalam bentuk menghubungankan antara total penghasilan yang dilaporkan dalam pajak penghasilan satu tahun pajak dengan total pajak keluaran yang dilaporkan 
dalam PPN dalam satu tahun pajak; (2) matchng data pengawasan dengan data eksternal terkait isi SPT antara lain memanfaatkan sistem silang informasi antar wajib pajak (approval sistem), perbankan serta badan lainnya yang terkait, dan (3)Hasil pengawasan ketepatan waktu penyampaian SPT serta besarya pajak yang dibayarkan.

Badan Usaha PNTB melakukan penyerahan wilayah Lombok antara lain di Lombok Barat 57 agen di 5 kecamatan, Lombok Utara 37 agen di 4 kecamatan, Lombok Timur 79 agen di 4 Kecamatan dan Kota Mataram 37 Agen di 5 kecamatan. Untuk terdaftar sebagai agen, calon agen perlu memiliki ijin resmi atas badan usahanya dan mendapatkan rekomendasi Dinas Pertanian Nusa Tenggara Barat, penandatangani kontrak kerjasama dengan pihak penyalur (PNTB). Untuk bisa melakukan pemesanan pupuk subsidi melalui penyalur resmi, agen terlebih dahulu harus terdata dalam kuota yang disetujui oleh produsen sehingga pendataan agen baru hanya bisa dilakukan sebelum pendataan kuota tahun berikutnya berakhir.

Proses penyerahan distributor kepada agen, dimulai dengan pendataan permintaan dari distributor berupa proses permohonan barang. Permohonan tersebut dikirimkan kepada pihak PNTB oleh agen dan di tembuskan validasinya oleh agen tersebut via sms kepada Pihak produsen secara langsung dengan format tertentu. Permohonan agen secara tertulis kepada PNTB akan ditindaklanjuti dengan mengisi aplikasi khusus yang sudah terintegrasi langsung oleh sistem produsen dan penyaluran kepada agen menggunakan stok yang memang sudah tersedia pada PNTB. Proses administrasi tersebut merupakan salah satu upaya pengamanan terhadapan penyaluran barang subsidi oleh pihak produsen yang tidak terkait pada sistem perpajakan atau pelaporan pajak yang dilakukan oleh Pihak Badan Usaha PNTB.

Setelah proses tersebut selesai, pihak Badan usaha PNTB melaporkan seluruh penyerahan kepada staf perpajakan (NS\#1)) yang khusus menangani administrasi pelaporan dan penerbitan faktur pajak. Terhadap total yang dilaporkan oleh bagian penjualan (NS:\#2) akan dikoordinasikan kepada bagian pembukuan induk (NS\#3), untuk memastikan tidak terdapat kesalahan terhadap data tersebut. Pemrosesan data menuju administrasi pemajakan selanjutnya dilakukan sebagaimana proses pada penjelasan SAS PPN sebelumnya.

Diawali dengan melihat ketersediaan nomor faktur untuk memastikan bahwa setiap transaksi akan terakomodir dalam proses pembuatan bukti transaksi. Berdasarkan PER 24/PJ 2012 faktur pajak dibuat berdasarkan waktu penyerahan barang atau dana atau mana yang mendahului, namun Badan Usaha PNTB menggunakan jenis faktur pajak gabungan yaitu faktur yang dibuat paling lambat akhir bulan penyerahan. Ketentuannya adalah satu faktur merupakan akumulasi penyerahan baik sebagian ataupun seluruhnya yang dilakukan 1 (satu) bulan kalender atau satu masa pajak untuk satu pembeli .

Faktur pajak wajib dibuat oleh seluruh Pengusaha Kena Pajak dalam setiap transaksi penyerahannya. Namun untuk komoditi khusus sebagaimana yang dipasarkan oleh Badan Usaha PNTB, penyaluran, hingga Harga Eceran Tertinggi dan perjenjang ditentukan melalui ketetapan khusus Peraturan Menteri Pertanian 01/2020 tentang Alokasi dan Harga Eceran Tertinggi Pupuk Bersubsidi Sektor Pertanian Tahun Anggaran 2020 antara lain Pupuk Urea =Rp. 1.800; per 
kg;Pupuk SP-36 = Rp. 2.000; per kg; Pupuk ZA = Rp. 1.400; per kg;Pupuk NPK = Rp. 2.300; per kg;Pupuk NPK Formula Khusus = Rp. 3.000; per kg;Pupuk Organik = Rp. 500; per kg.

Untuk mekanisme PPN DTP diatur dalam PMK 62/PM.03/2015 tentang Nilai lain dalam faktur pajak menjadikan kode faktur masukan yang diterima Distributor berkode "040: dengan nilai 10\% dari 100/110 bagian Harga Eceran Tertinggi" atau DPP Nilai Lain. Maksud dari DPP Nilai adalah penentuan dasar pengenaan yang didasarkan pada nilai tertentu yaitu 100/110 dari HET berlaku bukan dari nilai penyerahan produsen kepada agen. Tentang penyerahan distributor terhadap agen, PMK 62/PM.03/2015 tentang Nilai Lain dalam faktur pajak tidak mengatur 0tentang mekanise distributor keagen.

Selaku juknis bagi PNTB dalam menyelesaikan kewajiban pajaknya, pasal 9 ayat 1 menjelaskan tentang ketentuan pengkreditan pajak masukan namun tidak ada pasal yang menjelaskan mengenai pajak keluaran. Atas permasalahan ini, disimpulkan bahwa tidak adanya pengecualian membuat pelaksanaan SAS PPN PNTB harus mengikuti mekanisme sebagaimana peraturan yang termanifestasi dalam e-faktur 2.2, upaya konsultasi maksimal tidak juga menemukan titik terang

"...belum jelas kodenya, kami khawatir yang kami sampaikan tidak berdasar. Menurut saya ada dikode 07 tapi kalau ibu mau pakai 08 itu juga bukan kesalahan, tergantung pemeriksa pajaknya nanti, karena hasil akhir ada diperspektif mereka pada saat pemeriksaan. masalahnya pupuk ini tidak ada dalam listnya PPN dibebaskan ataupun tidak dipungut. Sedangkan PKP tetap wajib buat faktur ...." ujar AR PNTB.

Kewajiban pembuatan faktur adalah wajib bagi seluruh penyerahan yang dilakukan oleh Pengusaha Kena Pajak. Status inilah yang mengikat seorang pelaksana usaha sebagai wajib pajak untuk memenuhi ketentuan pada UU. No 42 tahun 2009 Pasal 13 ayat 1 " Pengusaha Kena Pajak wajib mebuat faktur pajak untuk (a.) Penyerahan Barang Kena pajak-sebagaiana pasal 16D, (b) Ekspor sebagaimana pasal 4 ayat 1 huruf h, dan (c) Penyerahan Jasa Kena Pajak sebagaiana pasal 4 huruf c " . Dalam prakteknya, user administrator e-faktur2.2 Badan Usaha PNTB menggunakan kode "070" sebagai jalan sebagai upaya pemenuhan UU No 42 tahun 2009 pasal 13 ayat 1. Sebab pupuk besubsidi jenis NPK , Urea , ZA dan SP 36 merupakan barang kena pajak. sebagaimana pasal 13 ayat 1 UU No 42 tahun 2009 yang di pertegas ikatannya dengan Badan Usaha PNTB melalui PMK 62/PM.03/2015 pasal 9 ayat 3 jika Badan Usaha penyalur pupuk merupakan PKP maka wajib mengikuti aturan perundang undangan.

Wadah regulasi dalam menghindari kerancuan yang ada di dalam pasal 9 ayat 2 diberikan pilihan tentang tidak wajibnya seorang distributor dan agen menjadi PKP merupakan angin segar, sebab pasal ini diharapkan dapat melepaskan Badan Usaha PNTB dalam status PKP. Namun manfaat Pasal 9 ayat 1 PMK 62/PM.03/2015 di dangkalkan manfaatnya pada ayat 2, bahwa tidak wajibnya PKP hanya berlaku bagi Penyalur yang semata mata menyalurkan pupuk. Pelaksanaannya, Badan Usaha PNTB selain mendistribusikan pupuk juga diberikan fasilitas penyewaan gudang sebagai tambahan jasa oleh produsen. Lemahnya pasal 9 ayai 1 dan 2 juga lebih dipertegas adanya pasal 3 yang mengembalikan PNTB dalam status PKP dibawah naungan UU no 42 tahun 2009 
Sebelum diterapkannya PMK62/PMK03/2015, Produsen memang mengharuskan penyalur adalah PKP. Sedangkan batasan pendapatan lebih dari 4,8 Milyar dalam satu kali transaksi atau satu periode tahun pajak. Apabila suatu lembaga sudah memenuhi batasan tersebut maka wajib mengajukan diri sebagai pengusaha kena pajak atau dapat pula dikukuhkan secara jabatan (oleh Direktorat Jenderal Pajak) . Dari segala aspek yang ada maka proses pencabutan PKP tertolak dan Badan Usaha PNTB harus melanjutkan mekanisme sementara administrasi pajak keluaran e-faktur 2.2 dengan juknis yang ambigu. Pengadiministrasian Pajak Pertambahan Nilai memang merupakan hal yang sangat krusial, setiap kesalahan bernilai denda, penilaian atas kelemahan regulasi bukan mudah untuk diselesaikan. Kendati demikian, proses administrasi faktur keluaran harus tetap dijalankan.

SAS PPN pada dasarnya dilaksanakan dalam tujuan memenuhi kriteria kepatuhan perpajakan yaitu Berdasarkan buku rahayu tahun 2009 dijelaskan, indikator kepatuhan wajib pajak adalah wajib pajak mengisi SPT dengan benar, lengkap dan waktu serta tidak pernah menerima surat teguran. Wajib pajak patuh hanya indicator awal namun setiap isi laporann tentunya akan menjalani pengawasan, rekonsiliasi dengan informasi badan lainnya. Namun peneliti tidak membahas lebih jauh tentang hal ini dikhawatirkan bias pada permasalahan awal. Mengingat operasional SAS PPN dalam e-faktur adalah menjadi hal dasar penelitian bukan pengawasan meskipun merupakan satu rantai proses keberlanjutan dari hasil laporan wajib pajak namun berbeda otoritasnya.

Apapun permasalahan dalam Administrasi fakur pajak keluaran dalam $e$ faktur 2.2 tentunya akan tetap terproses sebagaimana prosedur dalam mekanisme pembuatan SPT. Aplikasi akan secara otomatis terupload dalam sistem $e$ faktur2.2 ketika user meminta pembuatan SPT tersebut. Yang perlu diamati adalah proses ini akan memberikan nilai beban secara normal kepada setiap transaksi yang dioperasikan sebagaimana penjelasan sebelumnya yaitu $10 \%$ dari penyerahan. Sebelum memasuki formulasi lanjutan, dalam pasal 9 ayat 1 PMK62/PMK03/2015 menjelaskan atas ransaksi pupuk bersubsidi tidak diperlukan proses pemungutan PPN namun pada dasarnya adalah tehutang dan Ditanggung pemerintah dilini produsen dengan ketentuan pengajuan subsidi sebagaimana tertera pada PMK 62/PMK03/2015.

Pada jalur pembelian, faktur yang diterima distributor/PNTB adalah faktur yang terlebih dahulu sudah mendapat approve dari sistem DJP melalui aplikasi managemen uploder e-faktur2.2. Approval Pajak Masukan merupakan menu yang menghubungkan PNTB/user dengan DJP dalam meperoleh ersetujuan pengkreditan faktur masukan sebagai pengurang beban pajak keluaran. Upload perekaman faktur pajak masukan akan dilakukan distributor/Badan Usaha PNTB terkait faktur tersebut atas kegiatan pembelian. Proses upload tersebut dapat di"approve" atau di"reject" disebabkan permasalahan identitas, nilai, nomor yang digunakan, dan atau kode seri enofanya adalah palsu. Inilah wujud Pengendalian nomor seri faktur melalui sistem e-Nofa yang dikendalikan melalui approval sistem pada aplikasi e-faktur 2.2 proses ini dapat mencegah kerugian pembeli terkait adanya kesalahan ataupun faktur dari supliernya. Berikut adalah data faktur yang dterima Badan Usaha PNTB sejak tahun 2014-2017. 
Tabel 2. DaftarPenerimaan Faktur Pembelian 2014-2017

\begin{tabular}{llll}
\hline Tahun & Faktur Diterima & Reject Sistem & Appv sukses \\
\hline 2014 & 466 & 0 & 466 \\
2015 & 339 & 0 & 339 \\
2016 & 414 & 163 & 251 \\
2017 & 178 & 112 & 66 \\
Jumlah & 1397 & 275 & 1122 \\
\hline
\end{tabular}

Sumber : Data penelitian, 2020

e-faktur berlaku sejak 1 juli 2016 namun, sebelumya berlaku sistem eSPT dalam pelaporannya, perbedaan mendasar diantara keduanya adalah fitur tambahan berupa validasi faktur serta aproval sistem sehingga pada tahun 2014 dan 2015 seluruhnya berhasil di input kedalam SPT artinya sukses. Pada tahun 2016 sejak menggunakan e-faktur setiap penerimaan bukti pembelian, distributor menerima faktur pembelian mereka dengan status faktur pajak standar yang tervalidasi system DJP. Faktur terebut dan berstatus "sukses", namun faktur pembelian tersebut direject antara lain 163 faktur dari 414 faktur yang diterima dan selanjutnya belanjut 112 faktur dari 178 ditahun 2017.

Berdasarkan hasil observasi data diketahui, terdapat kesalahan pada NPWP yang diterbitkan produsen namun nama yang ditulis oleh produsen benar. Masalah yang sederhana namun membutuhkan penyelesaian yang tidak mudah. Atas permasalahan ini, diperlukan penyelesaian dengan komunikasi antara DJP, distributor dan produsen terkait sistem silang infomasi dalam database yang dimiliki.

Proses permohonan penggantian faktur tidak dapat diakomodir oleh produsen. Permasalahan mendasar ada pada sistem yaitu persediaan e-Nofa pada masa yang sama tidak mencukupi. Kesalahan NPWP atau indentitas tidak dapat di lakukan dengan pengeditan atau mengganti dengan faktur pengganti (dengan nomer yang sama). Faktur pengganti hanya diperbolehkan pada revisi nominal transaksi, masa pajak, dan lainnya kecuali identias pembeli (NPWP,Nama dan alamat). NPWP (Nomor Pokok Wajib Pajak ) dalam Undang Undang KUP pasal 1 menjelaskan bahwa NPWP adalah nomor yang diberikan kepada wajib pajak sebagai sarana dalam administrasi pemajakan yang digunakan sebagai alat pengenalan diri dalam melakukan hak dan kewajiban perpajakannya.

Keadaan ini menggambarkan belum sempurnanya efaktur 2.2 dalam mengakomodir kemanaan faktur yang diterima lawan transaksi, sebab faktur dari produsen adalah faktur yang sudah berstatus "approve" pada sistem penjualan produsen dan reject pada sistem pembelian distributor, sedangkan kesalahan produsen terletak pada ketidak sesuaian antara NPWP dan Nama yang diterbitkan, secara normative bila disebutkan efaktur demi keamanan bukti transaksi dengan validasi sistem. Mengenai sistem silang informasi yang juga menjadi kelebihan fitur ini, berdasarkan kesalahan yang demikian akan menimbulkan ketidak seimbangan pada equalisasinya atau proses pencocokan transaksi baik distributor ataupun Badan Usaha yang dituju pada NPWP yang tertera. 
Masalah ini dalam proses silang informasi akan mempengaruhi informasi yang disampaikan Badan Usaha PNTB kepada DJP, yaitu tidak terdeteksinya nilai pembelian atau pada bukti yang bermasalah, namun data penjualannya terdata milik produsen akan tetapi pembeliannya terdata milik NPWP badan usaha lainnya. Akibatnya, Badan Usaha PNTB seolah tidak memiliki pembelian pada periode 1 juli 2016 s.d 2017 atas sejumlah faktur yang ditolak tersebut. Mengantisipasi masalah ini, distributor melakukan permohonan penggantian faktur sudah diajukan namun masalah mengambang sampai dengan masa penelitian ini dilakukan belum juga menemukan titik temu permasalahan. Artinya faktur tersebut tidak diberikan penggantian dengan status apapun dan tidak diberikan surat keterangan. Kelemahana sistem efaktur tersebut menjadi jelas ketika keabsahan faktur diberikan pada kesalahan NPWP yang menjadi identitas kunci pada transasksi perpajakan.

Atas faktur yang diterima dari produsen berkode"040" dan diberlakukan nilai lain, maka kode ini adalah tepat sebagaimana UU No 42 tahun 2009 dan juknis kode faktur pajak dalam PMK terkait yang berlaku secara umum namun karena PPN tidak di tentukan dengan nilai penyerahan melainkan HET. Pemungutan tidak dilakukan berdasarkan mekanisme administrasi Pajak Masukan namun terbentuk dari harga tebus yaitu:

Harga Tebus $=100 / 110$ dari harga beli $+(10 \% \times(100 / 110 \times$ HET $)$

Karena Faktur pajak masukan ini tidak dapat dikreditkan, unsur $10 \%$ tambahan harga beli tergantikan melalui harga jual barang kepada agen, hanya tidak seimbang jumlahnya disebabkan pembentukan harga agen adalah sesuai marginnya. Sehingga PPN pupuk ditegaskan adalah beban dan dibayarkan oleh pemerintah dengan mekanisme penagihan yang hanya bisa dilakukan oleh produsen sebagaimana diatur dalam PMK 62/PMK03/2015. Ketidak seusiannya jumlah selisih PPN yang masih mengikuti harga jual dan beli tidak menghasilkan nol, artinya terdapat beban harga sedikit lebih tinggi di lini distributor dibandingkan sebelum berlakunya PMK 62/PMK03/2015

Upload Sistem DJP merupakan fitur yang mengakomodir informasi antara badan usaha atau yang disebut sistem silang informasi sebagaimana juga yang dilakukan pada SAS PPN pada beberapa negara di dunia. Selain juga berfungsi langsung pada pemenuhan kewajiban pelaporan secara efilling. Termanifestasinya aturan SAS PPN Pada fitur efaktur 2.2 yang dilengkapi sistem validasi online (approval sistem pada administrasi faktur masukan dan keluaran) dalam manajemen uploader e-faktur 2.2. Proses ini pada akhirnya akan menyambungkan seluruh kegiatan aktifitas penjualan dan pembelian dan melakukan pengkasifikasian berdasarkan kode pada faktur dengan status "approval sukses". Selajutnya proses perhitungan secara otomatis jumlah besaran pajak yang belum dipungut atau terutang.

Jumlah PPN terhutang bisa kurang bayar, nihil atau lebih bayar. Kurang bayar pajak pertambahan nilai merupakan posisi ketika nilai $10 \%$ dari DPP/ Dasar pengenaan pajak ( DPP penjualan $\times 10 \%$ ) lebih dari $10 \%$ dari DPP pembelian (10\% x DPP pembelian ). Mekanisme ini berlaku umum dan terhitung otomatis ketika efaktur 2.2 dioperasikan dan akan mengakumulasi transaksi sesuai masa / periode dan menghitung seluruh bukti penjualan dan pembelian 
yang berstatus "approval sukses" baik untuk pembelian ataupun penjualan yang sudah dikelompokkan berdasarkan kode faktur sebagaimana penjelasan diatas

Hasil dari pengelompokan ini akan mengkalkulasi sesuai fasilitasnya yaitu untuk barang tidak dipungut (070), dibebaskan (080), transaksi pada bendaharawan (02) ataupun pemungut selain bendaharawan (030). Untuk transaksi pupuk subsidi, sebagaimana dijelaskan pada sub pokok administrasi faktur pajak keluaran, proses upload sistem administrasi pajak keluaran akan menghasilkan pajak terutang sebelum dikrangi pembeian. Muncul ketika transaksi yang di lakukan belum terselesaikan pemungutannya sehingga menyisakan beban bagi PKP untuk membayarkan bagian yang belum dipungut tersebut setelah dikurangi besarnya pembelian dengan status bahwa pembelian tersebut dalam harga belinya terdapat unsur PPN yang sudah dibayarkan pada produsen dan ditransaksikan tidak oleh pemungut ataupun bukan barang dengan fasilitas tertentu.

Kembali pada penjelasan PMK 62/PMK03/2015, faktur pembelian dengan yang diterima PNTB berkode 040 dengan status DPP Nilai lain yaitu 100/110 dari Harga Eceran Tertinggi (Pasal 3 ayat 2) dan tidak dapat dikreditkan (pasal 8(1)) dan dibayarkan oleh pemerintah (Pasal 3-3a) dengan mekanisme pasal 6 dan pasal 7 yang prosesnya dilakukan dijenjang produsen. Untuk Pajak Keluaran pada perspektif distributor atau penjualan pupuk kepada agen dipastikan seharusnya terdapat proses pemungutan pajak (pasal 9-1). Berdasarkan pemaparan tersebut maka secara normative tentang pupuk bersubsidi dipastikan tidak terdapat unsur PPN kurang atau lebih bayar. Pada prakteknya sebagaimana penjelasan adiministrasi pajak keluaran sebelumnya diketahui bahwa terdapat permasalahan penggunaan kode pajak 070 yang berarti terdapat unsur pajak namun tidak dipungut, penggunaan kode ini pada faktur pajak masih bersifat ambigu terkait kode ini melekat pada jenis BKPnya bukan pelaku penyerahan melainkan jenis BKPnya ditentukan khusus.

Mekanisme e-faktur2.2 dibuat untuk langsung mendesain laporan SPT melalui e-filling. e-filling adalah pelaporan online yang wajib dilakukan oleh wajib pajak dengan status PKP. Pelaporan disampaikan melalui laman DJP online yang bisa diakes langsung melalui DJP online dengan memasukkan NPWP dan password yang dibuat sendiri oleh wajib pajak. SPT yang dihasilkan secara otomatis akan melakukan penghitungan dan untuk PNTB pada pupuk ersubsidi dipastikan tidak memiliki nilai terhutang kecuali atas pupuk diluar jenis yag ditentukan. Seharusnya tidak dipungut namun harga tebus memiliki untsur PPN .

\section{SIMPULAN}

SAS PPN pupuk bersubsidi dijalankan melalui e-faktur, Sasarannya yaitu terpenuhinya kepatuhan perpajakan antara lain ketepatan waktu, kebenaran isi, menghindari adanya surat teguran maupun sanksi bunga dan denda administrasi. Substansi input aplikasi adalah transaksi penjualan, perekaman pembelian dan pembuatan SPT. Substansi penghubung antara bukti ketiganya adalah "approval sistem". sekaligus menjadi kunci silang informasi antara penjual,pembeli dan DJP. 
Prakteknya, faktur pembelian yang sudah tervalidasi "approve" tersebut ternyata masih dapat direject pada saat dioperasionalkan, . Pemecahannya yang tergolong sulit sebab terhambat ketersediaan E-nofa dari produsen. Hal ini membuktikan bahwa Approval sistem belum sepenuhnya dapat menjalankan fungsinya. Sepatutnya pada keadaan demikian, aplikasi setidaknya memberi peluang atas perbaikan dalam upaya konsultasi agar tidak menimbulkan kesalahan pada pada perspektif informasi yang disampaikan distributor pada SPTnya.

Pemenuhan dalam mencapai kebenaran substansi input sudah diupayakan dengan melakukan verivikasi informasi keakuratan data pada administrasi PNTB, namun permasalahan pada Administrasi faktur pajak keluaran efaktur 2.2 yaitu yang tidak terakomodirya PPN DTP searah permsalahan mendasar distributor mengenai status PKP yang wajib menerbitkan faktur pajak. Faktanya penjelasan PMK62/PMK03/2015 yang menyatakan tidak adanya pemungutan PPN pada jenjang distributor ke bawah kerap diartikan tidak diperlukannya faktur pajak. Lemahnya aturan yang mengakomodir sistem penjualan dan pembelian pada distributor pupuk subsidi terkait PPN menjadi cermin bahwa masih ada celah kekurangan efaktur 2.2 sebagai alat dalam mewujudkan SAS PPN sesuai peraturan yang mendukungnya mencapai kepatuhan perpajakan dalam perspektif kebenaran isi.

Berdasarkan telaah penelitian terdahulu pengguna dan pengusaan aplikasi dianggap searah dengan kepatuhan, namun secara kulatatif disampaikan ketersediaan enofa juga sangat berpengaruh, dan hal tersebut seluruhnya dapat diterima. Keberadaan masalah PPN DTP yang tidak terkomodir UU No 42 tahun 2009 juga benar menjadi permasalahan pada pelaksanaan aplikasinya (2015-2017). Temuan lain yang didapatkan adalah pembebanan harga termasuk PPN yang masih terjadi pada rantai jual beli distributor ke bawah terkait pembetukan harga jual, namun tidak ada proses pemungutan ataupun pengkreditan sebagaimana amanah PMK62/PMK03/2015. Fenomena ini menjadikan mekanisme indirect credit menjadi indirect cost, sehingga harga tebus produsen lebih tinggi dari yang ditetapkan, ini berdampak pada beban tambahan dan memotong margin keuntungan standar yang sudah ditetapkan pada margin distributor pada masa data penelitian antara tahun 20152017.

Dalam hal ini sangat disarankan adanya tax review perperiode transaksi guna memberikan penjelasan di kemudian hari. Sebab kerancuan antara regulasi dan operasional serta kegagalan sistem validasi merupakan permasalahan yang membawa dampak kedepannya dan diharapkan kedepan penelitian lainnya dapat membahas tentang pola pengawasan informasi e-faktur 2.2, terkait dampak anomaly operasional SAS PPN yang terjadi.

\section{REFERENSI}

Andryani, N. L. S. W. (2012). Analisis Tingkat Pemahaman Wajib Pajak Orang Pribadi Pada Pelaksanaan Self Assesment System Dalam Melaksanakan Kewajiban Perpajakan. Jurnal Ilmiah Akuntansi Dan Bisnis, 7(1), 1-25. Akuntansi, Jurusan Ekonomi, 
Copenhagen Economics. (2013). Vat in the Public Sector and Exemptions in the Public Interest. 1-268.

Das, A. (n.d.). With non - competitive firms, a turnover tax can dominate the. 8(9).

Dečman, M., \& Klun, M. (2015). The Impact of Information Systems on Taxation: A Case of Users' Experience With an e-Recovery Information System. The Electronic Journal of E-Government, 13(2), 110-121.

Gisbu, O. W., Kardinal, \& Kathryn. (2015). Pengaruh Modernisasi e- Nofa Terhadap Kepatuhan PKP dalam Penerapan Penomoran Faktur. 1-12. http://eprints.mdp.ac.id/1578/1/Jurnal.pdf

Han, E. S., \& goleman, daniel; boyatzis, Richard; Mckee, A. (2019). No Title. Journal of Chemical Information and Modeling, 53(9), 1689-1699.

Komal, \& Sirifort. (2013). An Analysis of the Impact of Value Added Tax (VAT ) in Delhi.3(3), 277-286. http://www.ripublication.com/gjmbs.htm\%0AAn

Keputusan Menteri Keuangan KMK No 544 TAhun 2000 tentang Kepatuhan Perpajakan

Muir, R. S. (1993). The Goods and Services Tax: Reflections on the New Zealand Experience, Six Years On The Goods and Services Tax: Reflections on the New Zealand. 3(2).

Musri, B. (2019). Aplikasi E-faktur Dalam Aturan Pemusatan PPN, pada PT X. JPAK: Jurnal Pendidikan Akuntansi Dan Keuangan, 7(2), 97-110. https://doi.org/10.17509/jpak.v7i2.17080

Nurma Ari Widyaningrum. (2012). Implementasi kebijakan..., Nurma Ari Widyaningrum, FISIP UI, 2012.

Peraturan Menteri Keuangan PMK No 228/200 jo PMK 237/2011

Peraturan Menteri Keuangan NPMK No62/PMK03/2015

Sarjana, P., Akuntansi, I., \& Akuntansi, D. (n.d.). Pengaruh Tax Avoidance Terhadap Cost Of Debt Indah Masri Dwi Martani.

Sudjono, S. (2016). Sistem Distribusi Berbasis Relationship: Kajian Penyempurnaan Penyaluran Pupuk Bersubsidi Kepada Petani. Analisis Kebijakan Pertanian, 9(4), 313. https://doi.org/10.21082/akp.v9n4.2011.313330

Sudrajat, A., Ompusunggu, A. P., \& Classification, J. E. L. (2015). Pemanfaatan teknologi Informasi, Sosialisasi Pajak, Pengetahuan Perpajakan, dan. 2(2).

Timmermans, B., \& Achten, W. M. J. (2018). From value-added tax to a damage and value-added tax partially based on life cycle assessment: principles and feasibility. International Journal of Life Cycle Assessment, 23(11), 2217-2247. https://doi.org/10.1007/s11367-018-1439-7

Tripathi, R., Sinha, A., \& Agarwal, S. (2011). The effect of value added taxes on the Indian society. 3(June), 32-39.

Undang -Undang No 42 Tahun 2009 tentang Pajak Pertambahan Nilai

Wibowo, D. H., Syafei, A., Zaky, G., \& Aziz, K. (2017). Implementasi Kebijakan Sistem E-Faktur 